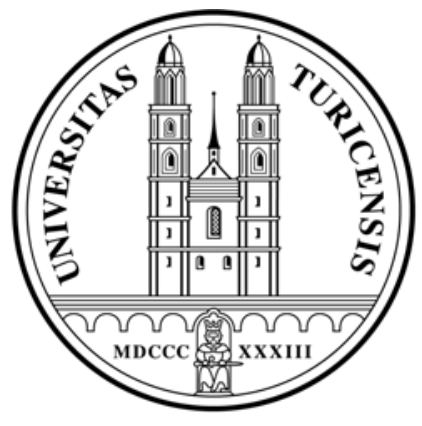

Institute for Empirical Research in Economics

University of Zurich

Working Paper Series

ISSN 1424-0459

Working Paper No. 304

\title{
Towards a Constitutional Theory of Corporate Governance
}

Matthias Benz and Bruno S. Frey

September 2006 


\title{
Towards a Constitutional Theory of
}

\section{Corporate Governance}

\author{
Matthias BenZ and Bruno S. FreY*
}

June 14, 2006

\begin{abstract}
The idea that there is a uniformly "optimal" governance structure for corporations features prominently in current debates and policy proposals. In this paper, we propose a different, constitutional theory of corporate governance: the criterion for a good corporate governance structure is whether it is freely chosen by the shareholders. We illustrate our approach by comparing the constitutional rights of shareholders under US corporate law and Swiss corporate law. Moreover, we discuss the mandatory provisions that shareholders would likely include in corporate law at a constitutional stage, behind the veil of ignorance. (91 words)
\end{abstract}

\footnotetext{
* Institute for Empirical Research in Economics, University of Zurich, Bluemlisalpstr. 10, CH-8006 Zurich, Switzerland. Tel.: +41 1634 3731. Fax:+411634 4907, e-mail: matbenz@iew.unizh.ch,bsfrey@iew.unizh.ch; and CREMA - Center for Research in Economics, Management and the Arts. We would like to thank Renée Adams, Christine Benesch, Lars Feld, Gérard Hertig, Karl Hofstetter, Silke Humbert, Simon Lüchinger, Susanne Neckermann and Alois Stutzer for helpful discussions and comments, and we gratefully acknowledge financial support of this project by the Ecoscientia Foundation.
} 


\section{Introduction}

The recent wave of corporate scandals has sparked an intense interest in the governance of business firms. Academic research on corporate governance is burgeoning, and policy makers as well as the general public continue to debate how corporate governance could be improved. Most of the current thinking on corporate governance is characterized by the view that there is a uniformly "optimal" governance structure for corporations. It features prominently in recent regulatory changes like the Sarbanes-Oxley Act, which imposes uniform regulations to move corporations closer to a more adequate governance structure. It also features in the "codes of best practice" of many countries, which have been formulated as a guidance for corporations how to improve their governance. But also practitioner circles and academic researchers often explicitly or implicitly subscribe to the view that there is an "optimal" governance structure for firms. Investors increasingly rely on corporate governance indices, such as provided by the US Institutional Shareholder Service, to rank corporations according to an "objective" corporate governance quality. Financial analysts apply similar "box ticking" approaches to determine the valuations of corporations. In doing so, they can base their judgments on a considerable body of academic research that has recently tried to uncover the relationship between different corporate governance structures and firm valuations (although with differing results, see e.g. Gompers, Ishii and Metrick 2003, Bebchuk, Cohen and Ferrell 2004, Brown and Caylor 2004, Daily, Dalton and Cannella 2003).

In this paper, we propose a completely different approach to corporate governance, which we term "constitutional". In this view, there is no uniformly "optimal" governance structure for corporations; rather, the criterion for a "good" corporate governance structure is whether it is freely chosen by the shareholders. Such a constitutional choice of shareholders can operate at two 
levels. First, within the context of a given corporate law, shareholders may be granted more or less constitutional rights to change the governance structure of a firm (embodied, for example, in the corporate charter or the articles of incorporation). The extent of these constitutional rights largely determines whether shareholders can institute a corporate governance system according to their preferences. Second, at the level of corporate law, current and potential shareholders may deliberate behind a "veil of ignorance" which provisions they would include as mandatory in corporate law and which issues they would leave to individual shareholder constituencies of firms. We discuss that shareholders would likely favor a corporate law that gives shareholders extended constitutional rights (including some influence over specific business decisions), while providing uniform regulations in some areas to ensure that shareholders preferences are properly transformed into corporate decisions and that minority shareholder interests are protected.

In order to illustrate our approach, we compare the corporate laws of the United States and Switzerland. US corporate law gives shareholders relatively few direct constitutional rights. Most corporate governance changes have to be initiated by the board, and if shareholders e.g. wish to change firm's charter or state of incorporation, they can only do so by electing a (new) board that will act according to their wishes (Bebchuk 2005, 2006). In contrast to this representative democratic approach, Swiss corporate law grants shareholders extensive constitutional rights; they can basically change a firm's constitution at any general meeting. Shareholders thus have ample possibilities to install a corporate governance structure according to their wishes. From a constitutional point of view, this characteristic makes Swiss corporate law preferable over US corporate law. It is thereby immaterial what governance structure shareholders actually opt for in specific cases. The constitutional theory of corporate governance makes no inferences, for example, about the undesirability of staggered boards or the advantages of independent audit 
committees. What is important is that shareholders have the constitutional possibilities to install or abolish these governance elements as they see fit.

Of course, a corporate law that would leave all corporate governance decisions to shareholders' discretion would likely be impracticable. The constitutions of particular firms are embedded within the larger framework of corporate law, and it is thus interesting to think about the mandatory provisions that shareholders (and other stakeholders) would write into superordinate corporate law at a constitutional stage, behind a veil of ignorance. An analysis of such a constitutional choice can be based on insights from constitutional economics, which has investigated the choice of rules in the political sphere (Buchanan and Tullock 1962, Frey 1983, Mueller 1996, Cooter 2000). We draw an analogy to this literature and show that the relevant concepts can also be meaningfully applied to the analysis of corporate law at a constitutional stage. While it is difficult to determine how such a corporate law would exactly look like, the analysis points out that it would likely grant extended constitutional rights to shareholder constituencies of specific corporations.

To our knowledge, there are no studies in the literature so far that have approached corporate governance from a constitutional perspective. A few authors have applied a constitutional framework to the theory of the firm, most notably Gifford (1991), Vanberg (1992), Wolff (1997), Kaisla (2001) and Romme (2004). However, these authors do not use their analyses to address problems of corporate governance. Other researchers, e.g. Hermalin and Weisbach (2006), have taken a "contractarian" view on corporate governance, investigating the limits of state regulation, but they do not specifically analyze the constitutional rights of shareholders as a precondition for successful "private contracting". Closest to the approach proposed here is the work by Bebchuk (2005, 2006), who has argued that shareholders in the United States should be given more 
freedom to make "rules-of-the-game" decisions (i.e. constitutional rights). While being complementary to Bebchuk's analysis, our approach proposes the constitutional view as a general, unified perspective to analyze problems of corporate governance.

The paper is structured as follows. Section 2 outlines the constitutional approach to corporate governance. It sets out the theoretical basis of the approach, describes the resulting criteria to evaluate corporate governance systems, illustrates the approach by comparing US corporate law to Swiss corporate law, and discusses some analogies to constitutional rights in the political sector. Section 3 analyses the constitutional choice of corporate law at a higher level, behind the veil of ignorance. In section 4, counterarguments against a constitutional theory of corporate governance are discussed. Section 5 offers some concluding remarks.

\section{The Constitutional Approach to Corporate Governance}

\subsection{Theoretical perspective}

The debate on corporate governance has been dominated by the view that there is an "optimal" corporate governance structure that corporations should aspire to. On the one hand, this view has been prominent in the academic discourse. For example, principal-agent theory has argued for the introduction of more pay-for-performance incentives for top managers (Jensen and Murphy 1990), or management theory has intensively debated about the perils or advantages of CEOChairman duality (Dalton et al. 1998). On the other hand, the view also features prominently in policy proposals on corporate governance reform (Hertig 2005) and in practitioners' views of corporate governance. For example, investors are increasingly demanding corporate governance rankings that "objectively" rate corporations according to their governance quality (Koehn and 
Ueng 2005). A prominent index in this respect is provided by the US Institutional Shareholder Service, which ranks corporations based on 63 criteria, ranging from board composition to management compensation and director education (ISS 2006).

Interestingly, the focus on a uniformly optimal governance structure is not implied by the most important approach in the debate from a scientific point of view, principal-agent theory (Jensen and Meckling 1976, Shleifer and Vishny1997, Daily, Dalton and Canella 2003). Principal-agent theory analyzes the conflict of interest between principals (shareholders) and agents (management), and it assumes that a well-functioning market for corporate control will find different mechanisms to alleviate the resulting agency costs (though never fully eliminate them). In principle, each firm should find a governance structure that is well suited to its particular agency problems, consisting e.g. of different degrees of performance pay for executives or different structures of the board. However, principal-agent theory has rarely addressed the question to what extent principals can actually install a governance structure according to their wishes. For example, a crucial question is: Who, in actual fact, has the right to decide on whether a firm is taken over, a board is given a new structure, or a pay-for-performance plan is introduced?

The constitutional approach to corporate governance puts this question at the core of analysis. Shareholders can in principle have different rights to change the governance structure of a firm. These rights are usually defined by superordinate corporate law and cannot be easily altered by individual shareholder constituencies (without re-incorporating the firm in a different 
jurisdiction). ${ }^{1}$ Thus, corporate law importantly shapes the decision rights of shareholders in corporate matters.

The constitutional rights of shareholders in principle cover two different classes of decisions. First, there are "constitutional" decisions, i.e. decisions to change the corporate charter or articles of incorporation (they also have been called "rules-of-the-game" decisions by Bebchuk 2005, 2006). Second, there are specific business decisions, which cover the decision to merge or dissolve a company, to change the capital structure of the firm, or to pay out dividends, but which may also include issues such as determining the compensation structure for top management or the design of corporate social responsibility programs. Different corporate laws grant shareholders different rights regarding these constitutional and specific business decisions. This largely determines whether shareholders can institute a corporate governance system according to their preferences. Therefore, the constitutional theory of corporate governance puts the constitutional rights of shareholders at the centre of analysis.

By emphasizing shareholders' rights, the constitutional approach takes into account that the environments in which firms operate often change rapidly and in unpredictable ways. It is difficult, if not impossible, to predict which industries and markets will be dominant in the future, how corporations will have to adapt their organization and governance structures to the new environment, and what the preferences of the then shareholder constituencies will be. As a consequence, there is no "optimal" governance structure that is perfectly adapted to all current

\footnotetext{
${ }^{1}$ This is also the main reason why the market for corporate control will not automatically lead to efficient corporate governance structures. If the same corporate law applies to all firms in a jurisdiction, they can differentiate their governance structures only to a limited extent, because some elements are regulated by law. Of course, there is also competition between different jurisdictions providing corporate law (e.g. among the US states). However, it has been argued that this market for corporate law is not functioning well enough to take shareholders' preferences fully into account (for a survey, see e.g. Bar-Gill, Barzuza and Bebchuk 2006).
} 
and future contingencies. In contrast, the constitutional perspective takes a rules-based view, by stressing shareholders' constitutional possibilities to install or abolish governance elements as they see fit in a dynamic environment.

\subsection{Criteria for a "good" corporate governance system}

The focus of the constitutional approach on rights, rather than on specific governance outcomes, implies very different criteria to assess the "quality" of a corporate governance structure than other approaches. There is a single criterion: A corporate governance structure is preferable over another if shareholders have more rights to (at least potentially) decide over it. Other criteria are not relevant from a constitutional point of view. In particular, it is immaterial whether shareholders actually choose governance structures that are currently seen as desirable (e.g. abolishment of staggered boards, more independent board members). It is also unimportant whether the chosen governance structures actually lead to higher firm valuations. The only essential element is whether shareholders have constitutional possibilities to install or abolish governance elements as they see fit. (There are some restrictions that shareholders and other stakeholders would set behind a veil of ignorance, and we will discuss these restrictions in sections 3 and 4 below).

The focus on constitutional rights stands in the economic tradition to take individual preferences as the only standard of valuation. As a consequence, the constitutional approach shares the theoretical foundation with e.g. principal-agent theory, which puts shareholders' preferences at the centre of analysis (Jensen and Meckling 1976), or constitutional economics or public choice, which employs citizens' preferences as the standard of evaluation in the political sphere (Frey 1978, Mueller 2003). To illustrate the importance of this methodological foundation, consider the 
statement made above that firm valuation is no criterion to assess the quality of a governance structure from a constitutional point of view. While most shareholders may indeed only care about share prices, it would be a far too narrow view of shareholders' preferences to assume that all investors are exclusively interested in monetary returns (for evidence, see e.g. Moskowitz and Vissing-Jorgensen 2002). There may be groups of shareholders who are willing to pay a price, for example, for a particularly sensible corporate social responsibility program or for environmentally friendly production. Similarly, shareholders may have a preference for certain governance structures even if this lowers share price. Assessing these governance structures based on firm valuations alone would falsely characterize them as "inadequate" if shareholders actually had the constitutional right to freely install them at a particular firm.

If constitutional rights are the sole criterion to evaluate corporate governance structures from a constitutional point of view, what is the standard to classify constitutional rights as "superior" and "inferior"? A simple rule is to define a set of constitutional rights as preferable over another if it restricts shareholders' actual or potential possibilities to express their preferences to a lesser extent. The terms "actual or potential" indicate that shareholders need not always decide over a corporate matter from the constitutional point of view. For example, most shareholders will prefer to delegate the setting of management compensation to the board most of the time. But shareholders may or may not have the right to decide whether they want to have a say over this corporate matter or whether they rather want to delegate it. This "choice whether to have a choice" is important, as it serves as a credible threat even if shareholders do not in fact decide over a specific matter.

The criteria presented can be applied to rights regarding all constitutional or specific business decisions in corporations, ranging from the choice of how to structure the board to the 
determination of a corporate social responsibility policy. The constitutional approach to corporate governance is illustrated in the following by comparing US corporate law and Swiss corporate law.

\subsection{A comparison of US and Swiss corporate law}

The corporate laws of the United States and Switzerland are interesting to compare, because they grant shareholders very different degrees of constitutional rights in corporate matters. The US corporate law can be characterized as a "representative democratic system". It does not grant shareholders the right to directly initiate corporate governance changes or to propose specific business decisions; rather, the respective decision authority is vested in the board (e.g. Kraakman et al. 2004, Blair and Stout 1999, 2001, Bebchuk 2005, 2006). If shareholders wish to initiate changes in the governance structure of a firm, they can essentially only do so by electing a (new) board that agrees to submit the desired changes to a shareholder vote. Thus, shareholders have no possibility to induce corporate governance changes against a board's preferences. In contrast, Swiss corporate law is considerably more "direct democratic" (for overviews, see Forstmoser, Meier-Hayoz and Nobel 1996, Becchio et al. 1996). Shareholders are granted extensive constitutional rights to initiate changes of the constitution of the firm and to propose specific business decisions. There is no need for shareholders to elect a new board; rather, changes can be proposed directly and the existing board can be mandated to execute them. It is convenient to illustrate these differences between US and Swiss corporate law using four examples, two concerning constitutional decisions and two concerning specific business decisions.

Abolishment of staggered boards. The structure of the corporate board is a crucial element of the constitution of the firm. For example, the term lengths of the members of the board are specified 
in the corporate charter / bylaws in the United States or in the articles of incorporation in Switzerland. The corporate laws of both countries permit term lengths of more than one year, which creates the potential problem of staggered boards: If the term length is e.g. three years, only a third of all directors can be removed from the board in a given year. Shareholders in the United States have found it to be very difficult to repeal staggered boards (by shortening the term lengths of directors), because such a change in the firm's constitution has to be brought forward by the board itself (Bebchuk 2005: 851-856). Conversely, shareholders of Swiss firms have the right to directly propose a respective change of the articles of incorporation. A binding shareholder vote to abolish a staggered board can be requested by any shareholder or shareholder group holding more than 1 Mio. CHF of share capital or 10 percent of the shares (Swiss Code of Obligations §699.3; Forstmoser, Meier-Hayoz and Nobel 1996: §23, N27). Thus, Swiss corporate law grants shareholders an extended constitutional right to express their preferences over the structure of the board.

Direct election of the chairman. Another constitutional element that has been much debated in the literature is the separation between the chairman of the board and the CEO (Dalton et al. 1998). Under US corporate law, the corporate charter or bylaws specify the procedure to elect the chairman of the board, and it is generally the board's duty to appoint one of its members for this position (Delaware General Corporate Law §142, Model Business Corporation Act §8.40). As changes of the charter / bylaws have to be initiated by the board, shareholders' possibilities to install a different election system are severely limited. This makes it difficult to install a separation of the chairman / CEO position against the board's preferences. In contrast, Swiss corporate law explicitly grants shareholders the right to change the constitution of the firm such that they can directly elect the chairman of the board (Swiss Code of Obligations §712.2). 
Shareholders of Swiss companies thus possess the constitutional right to request a direct election of the chairman if they see this as an important element to improve the governance of a firm.

Dividends. With respect to specific business decisions, the distribution of dividends constitutes an important element. Dividends transfer assets from the corporation to shareholders. Thus, they play a role in determining the "size" of a corporation and in alleviating potential agency problems, such as empire building by managers or misuse of free cash flow. US corporate law puts the decision whether to pay out a dividend and of what amount into the board's discretion, unless the corporate charter provides otherwise (Delaware General Corporate Law $§ 170$, Model Business Corporation Act §6.40). As in the cases discussed above, shareholders do not have the right to initiate changes of the corporate charter and thus cannot install a specific dividend payout policy (Bebchuk 2005: 901-903). Swiss corporate law regulates the distribution of dividends differently. Shareholders have the right to freely specify how the corporate profit is used, i.e. whether it is (partly) distributed in the form of dividends or whether it is added to the corporate assets (Swiss Code of Obligations §698.2, Forstmoser, Meier-Hayoz and Nobel 1996: §22, N4148). Under Swiss corporate law, shareholders thus have extended constitutional rights to influence the distribution of corporate assets.

Management compensation. An even more specific business decision is the choice of how to compensate the top managers of a firm. However, the structure of management compensation is generally regarded as an important element of corporate governance in the literature (e.g. Jensen and Murphy 1990, Dalton et al. 2003, Frey and Osterloh 2005). US corporate law treats the decision of whether managers should receive strong performance-related pay (e.g. in the form of stock and stock options) or rather more fixed compensation as a normal business affair and therefore assigns the respective decision rights to the board (Delaware General Corporate Law 
$\S 141$, Model Business Corporation Act §6.40). Under current Swiss corporate law, the setting of management compensation is also considered as one of the inalienable duties of the corporate board (Swiss Code of Obligations §716a, Forstmoser, Meier-Hayoz and Nobel 1996: §30, N31). Thus, shareholders of Swiss corporations do not enjoy extended constitutional rights with respect to this specific business decision; they also do not have the "choice whether to have a choice" over the matter. However, a current reform of Swiss corporate law plans to introduce a respective constitutional right for shareholders, with the aim to move compensation practices closer to shareholders' preferences.

In sum, US and Swiss corporate law widely differ with respect to the constitutional rights they grant to shareholder constituencies of particular firms. The analysis demonstrates that the constitutional rights of shareholders under Swiss law are very extensive, vesting them with large discretion to initiate corporate governance changes and specific business decisions. In contrast to this "direct democratic" approach, US corporate law reserves most decision rights to the elected representatives of shareholders, the members of the corporate board. It has been argued that this constitutes one of the core strengths of the US corporate system, because it locks in capital to the firm and protects stakeholders from opportunistic behavior by shareholders (see e.g. Blair and Stout 1999, 2001, Hansmann and Kraakman 2004a). Contrary to this view, the constitutional approach to corporate governance suggests that extended constitutional rights for shareholders are desirable, as exemplified by Swiss corporate law. While counterarguments against the constitutional perspective will be discussed in detail in section 4 , it shall suffice here to mention that Swiss corporate law has not led to the negative results that may be expected from a critical point of view. Firms incorporated in Switzerland seem to be quite successful in attracting investors, creditors, employees and customers and consequently are among the largest 
corporations worldwide, e.g. in the banking, insurance, pharmaceutical and food sectors. Moreover, stock market capitalization relative to GDP is very high in Switzerland (about 65 percent higher than in the United States; Beck, Demirgüç-Kunt and Levine 2000), and there are essentially no serious conflicts between shareholders and other stakeholders like employees (Monger 2004).

\subsection{Analogy to direct democracy vs. representative democracy in politics}

The constitutional rights of shareholders stand in close analogy to the constitutional rights that citizens have in the political sphere (see also Benz and Frey 2006, Frey and Benz 2005). Citizens' rights to participate in political decisions are a crucial characteristic of any democratic constitution. In representative democracies, they typically comprise the right to vote in elections and to run for a seat in parliament, and in direct democracies, they additionally entail possibilities of launching and voting on referenda and initiatives. Political science and public choice theory routinely classify political constitutions as "direct democracies" or "representative democracies", in a similar way as the constitutional rights of shareholders can be classified into "representative democratic" and "direct democratic" systems. It thus seems interesting to shortly highlight how extended constitutional rights of citizens in the political sphere affect the governance of political entities.

While there is some disagreement about the relative merits of direct democracy, a growing body of empirical studies suggests that extended constitutional rights allow citizens to install public policies that are closer to their preferences (for extensive surveys, see Matsusaka 2005, Frey and Stutzer 2006). According to the evidence, direct democratic rights help citizens to alleviate similar agency problems as those existing in the corporate sector. For example, citizens with 
more direct democratic rights are more successful in restricting "empire building" by politicians (i.e. excessive expansion of government size), and they are able to more effectively align government activity with their interests. This suggests that extended constitutional rights of principals are not only important in corporate sphere, but that they also play an essential role in solving principal-agent problems in politics.

\section{The Choice of Corporate Law at the Constitutional Stage}

The analysis so far has considered the constitutional rights that shareholders are granted within a given corporate law. However, such an analysis is necessarily incomplete. Corporate law cannot simply devolve all constitutional rights to the individual shareholder constituencies of corporations; rather, it has to provide a set of basic mandatory rules to make the law functional (Hansmann and Kraakman 2004b). As a consequence, there are necessary limits to the constitutional rights that shareholders may enjoy. We have argued that these limits may be drawn relatively wide, without obvious dysfunctional consequences. Nevertheless, it seems important to think about the mandatory rules that corporate law ought to specify.

In this section, we argue that the constitutional approach can also provide a novel perspective on the question of mandatory provisions in corporate law. The constitutional view proposes the "veil of ignorance" as the criterion to assess generally binding rules (Buchanan and Tullock 1962, Rawls 1971, Frey 1983, Mueller 1996): What corporate law would individuals agree upon if they were behind a veil of ignorance, i.e. if they were not aware of their position and specific interests as shareholders, potential shareholders, employees or other stakeholders? While the veil of ignorance clearly is a hypothetical construct, it can nevertheless offer a fruitful perspective. In 
particular, corporate law is not taken as given, but it is analyzed how individuals would likely design corporate law and important corporate governance provisions at a constitutional stage.

Of course, applying the constitutional view to all relevant aspects of corporate law lies far beyond the scope of the present paper. Corporate law has many essential features that are common to the corporation laws of most developed countries, e.g. the concepts of legal personality, limited liability or the transferability of shares (for a survey, see Kraakman et al. 2004). The following analysis will be limited to the much narrower question of shareholders' constitutional rights in matters of corporate governance. The focus thus is on individuals' choice of constitutional rights at a constitutional stage, without knowledge about their positions and interests when the rights actually will be applied.

\subsection{Constitutional rights behind a veil of ignorance}

The field of constitutional economics, which has investigated the choice of rules in the political sphere, has developed a major principle for how individuals would rationally set rules behind the veil of ignorance. The core idea is that collective decision-making always entails a trade-off between "decision-making costs" and "externality costs" (Buchanan and Tullock 1962; see also Romme 2004, Marino and Matsusaka 2005 for applications to business organizations). Decisionmaking costs emerge because it takes time and resources to reach a collective agreement. If a collective decision has to be approved by a large majority of individuals (in the extreme, by unanimity), it entails high decision-making costs, while a collective decision that has to be supported only by a simple majority entails lower decision-making costs. In contrast, externality costs are inversely related to the level of the majority required for a collective decision. A unanimity rule ensures that collective decisions never impose an externality on an individual, 
because otherwise the individual would not approve the collective decision. Conversely, a simple majority rule entails higher externality costs, as in this case a majority can impose its preferences on a minority. Depending on the shape and the magnitude of decision-making and externality costs, there are different levels of "optimal" majority requirements for collective decisions. Thus, the constitutional approach focuses on the fundamental trade-off between the agreement costs and the externality costs that a collective decision involves.

Unanimity and mandatory provisions. A first application of the constitutional approach concerns the question of unanimity: Behind the veil of ignorance, for which corporate decisions would individuals require a unanimity approval of all shareholders and stakeholders? According to the constitutional view, this could either be the case because decision-making costs are very low or because externality costs are very high. For example, at the constitutional stage individuals may consider the situation of creditors. A large externality is imposed on creditors if shareholders decide to distribute the firm's assets without satisfying creditors' claims. Individuals may thus consider a unanimity rule for the decision to liquidate a firm, requiring approval of all shareholders and creditors. But a unanimity rule also would lead to very high decision-making costs. Therefore, individuals may rather opt for a mandatory provision, requiring that corporations fulfill their contractual obligations before any assets can be distributed. In fact, this is the rule contained in essentially all corporate law codes of developed countries (Hertig and Kanda 2004). Corporate law sets mandatory provisions in other areas where potential externalities are high and unanimity rules would lead to high decision-making costs. From a constitutional point of view, this is likely to reflect provisions that individuals would adopt behind a veil of ignorance. 
Supermajority requirements and minority protection. An application more closely related to corporate governance is the question of majority requirements for shareholder decisions. Even if no externalities are imposed on other stakeholders, the trade-off between decision-making costs and externality costs is still relevant. For example, the major corporate governance problem in many countries is not the conflict between shareholders and management, but the problem that majority shareholders can exploit minority shareholders (e.g. Djankov et al. 2005). Individuals who consider, behind the veil of ignorance, the potential externalities that majority shareholders can impose on minority investors will devise adequate rules to address this conflict of interest. One rule they are likely to adopt are supermajority requirements for shareholder decisions where externalities are most prevalent. Typically, those decisions would include changes in the firm's constitution and other important specific business decisions. In fact, the corporate laws of many countries require that the most important corporate decisions be approved not by a majority, but by a supermajority of shareholders. This is particularly the case in countries where shareholders are granted extensive constitutional rights and thus majority shareholders have large potential possibilities to exploit minority investors. Swiss corporate law, for example, requires that certain changes in the articles of incorporation be approved by 66 percent of shareholders (Swiss Code of Obligations §704), and UK corporate law prescribes an even higher supermajority requirement of 75 percent (Bebchuk 2005: 848). Individuals might also reasonably agree behind a veil of ignorance to other mandatory rules serving to protect minority shareholders, many of which form a common body of corporate law in developed countries (e.g. the rule of pro-rata distribution of dividends, Hansmann and Kraakman 2004a: 54-61).

Delegation of constitutional rights to the board. Would individuals decide behind the veil of ignorance to reserve extended constitutional rights for shareholders or to delegate many decision- 
making powers to the corporate board? The question again is one of trading off decision-making costs and externality costs. Extended constitutional rights would likely entail high decisionmaking costs for shareholders, but they would also lower the probability that externalities are imposed on them as a result of misguided board decisions. It is open whether individuals would adopt a mandatory rule at a constitutional stage that uniformly regulates the division of power between shareholders and the board. However, it seems more likely that individuals would leave this decision to the shareholder constituencies of particular firms. There is no obvious reason why the trade-off between decision-making costs and externality costs could not be assessed by the shareholder constituencies of particular firms, given that there are no externalities on other parties (see also section 4 on externalities). Different shareholder constituencies would likely adopt different governance arrangements, depending on the specific trade-off at a particular firm. If decision-making costs are high or externality costs are low, shareholder constituencies would probably opt for a more delegated structure, while in case of low decision-making costs or high externality costs, they would choose more direct involvement in decision-making. Individuals behind the veil of ignorance are therefore unlikely to strongly restrict the constitutional rights of shareholders in corporate law. Rather, they would probably opt for a shareholder right to "choose whether to have a choice", i.e. to decide whether a corporate issue is delegated to the board or whether it is dealt with by shareholders themselves. There seems to be no reason to assume a priori that this constitutional right of shareholders could not include decisions such as setting the structure of management compensation or designing corporate social responsibility policies. However, as argued above, individuals would presumably subject proposed changes in the governance and delegation structure of a firm to a supermajority requirement in order to protect minority shareholders. 
Ensuring shareholder representation. Behind the veil of ignorance, individuals may also consider rules that govern the most basic aspect of shareholder rights, namely the question of who should be entitled to vote in collective shareholder decisions. Individuals would probably not devise a rule that would force shareholders to vote or deprive them of the possibility of transferring their voting right to other parties, but they would likely conceive rules to ensure that those entitled to vote actually vote in the interest of the ultimate beneficiaries (for a similar argument, see Easterbrook and Fischel 1991). Two current issues related to shareholders' voting rights would probably attract individuals' interest behind a veil of ignorance: First, the practice of delegated voting by institutional investors or pension funds, and second, the practice of securities lending. Both practices entail the problem that those voting in actual shareholder decisions are not, or only indirectly, the beneficiaries of the actions decided upon. In case of delegated voting by institutional investors or pension funds, there is a governance problem of its own, as the representatives of funds might follow their own interests rather than those of the ultimate beneficiaries (e.g. Woidtke 2002, Gillan and Starks 2003). The practice of securities lending entails the problem that voting rights can fall in the hands of individuals who are only very shortterm economic beneficiaries, or who specifically borrow shares to influence voting results (Christoffersen et al. 2005); in addition, multiple voting rights may be created for a single share (Martin and Partnoy 2005). Individuals might consider rules behind the veil of ignorance to ensure the correct representation of shareholders' preferences in corporate decisions. For example, they could consider a mandatory rule that delegated voting is only permitted if the delegate has obtained approval for his voting strategy from the ultimate beneficiaries (this is essentially the rule, for example, in Swiss corporate law; Forstmoser, Meier-Hayoz and Nobel 
1996). Similarly, shares that are lent out might be mandated not to convey a voting right to the borrower (Martin and Partnoy 2005).

In sum, the constitutional approach to corporate law sheds an alternative perspective on existing corporation law and corporate governance practices. In some cases, applying the thought experiment of the veil of ignorance results in conclusions that are very similar to what is actually practiced in the corporate laws of many countries nowadays, e.g. with respect to the protection of creditors or minority shareholders. In other cases, the constitutional perspective tends to favor the corporate laws of some countries over others, e.g. with respect to the allocation of decision rights between the board and shareholders. In still other cases, the constitutional approach can only offer tentative guidance for how corporate law should proceed, e.g. with regard to current issues such as delegated voting or securities lending.

\section{Counterarguments Against a Constitutional Theory of Corporate Governance}

The constitutional approach to corporate governance can be criticized along several dimensions, some of which have already been discussed in the previous section. In the following, three main counterarguments shall be addressed in more detail. First, it can be argued that extended constitutional rights for shareholders would hurt the interests of other stakeholders, like employees. Second, it can be objected that shareholders would in fact profit from a full delegation of decision-making powers to the board, because this credibly 'ties the owner's hands". And third, extended constitutional rights may be seen as misguided because shareholders have weak incentives to be informed about corporate decisions and to participate in them. 


\subsection{Shareholders vs. other stakeholders}

The first counterargument against extended constitutional rights for shareholders makes the case that several agency problems exist within a corporation. There is a well-known agency problem between shareholders and management, and extended constitutional rights may help to alleviate it, but there are also other agency problems, such as the conflict between shareholders and employees (e.g. Hansmann and Kraakman 2004b, Blair and Stout 1999, 2001). An important function of corporate law is to protect employees (and other stakeholders) from opportunistic behavior by shareholders. As has been discussed in the previous section, the main instrument for achieving this is to provide legal protection to the contracts that employees and creditors engage in with the corporation.

From a theoretical point of view, however, there are other reasons why externalities may be imposed on stakeholders, even if they are protected by contract. In particular, this is the case if stakeholders make firm-specific investments. For example, employees may suffer a considerable externality if they have invested in firm-specific human capital and the employment relationship is terminated. The externality in this case consists of the foregone value of firm-specific investments to employees, which by definition are only valuable inside the firm and not outside on the general job market. The concept of firm-specific human capital is well-established in the literature; moreover, it can be precisely measured by the wage reduction that employees have to suffer in case of an external termination of the employment relationship. While there is some disagreement about the empirical relevance of firm-specific human capital, several studies have suggested that it is responsible e.g. for the phenomenon that wages rise with the seniority of employees at a particular firm (see e.g. Topel 1991, Flabbi and Ichino 2001, Dostie 2005, Lazear 2003). 
If firm-specific human capital is relevant, employees' interests should be given adequate protection in corporate governance (Furubotn 1988, Roberts and Van den Steen 2000, Osterloh and Frey 2005). It has been argued that it is the essential function of the corporate board to provide this protection (e.g. Blair and Stout 1999, 2001). Extended constitutional rights for shareholders are undesirable from this point of view, because they would seriously undermine the board's possibilities to balance the different agency conflicts within the firm as a neutral arbitrator.

In a constitutional perspective, however, the delegation of decision powers to the board is only one of many possible corporate governance arrangements that can serve to protect employees' firm-specific investments. In particular, employees' interests can also be secured by giving them voting rights in corporate decisions. From a constitutional point of view, corporate law should provide for the possibility that shareholders grant voting rights to employees. Shareholders would let employees participate in corporate decisions out of pure self-interest if these voting rights are crucial for giving employees incentives to invest in firm-specific human capital (Osterloh and Frey 2005). Thus, there are alternative methods to alleviate potential conflicts between shareholders and other stakeholders, and these methods are well compatible with extended constitutional rights for shareholders in corporate governance.

\subsection{Credible commitments: "Tying the owners' hands"}

A second objection to a constitutional view of corporate governance argues that shareholders would actually benefit from not having extended rights to interfere in corporate matters. The full delegation of decision-making powers to the board can serve as a "credible commitment" (e.g. Blair 2005, Miller and Falaschetti 1999). For example, delegating the decision over the 
distribution of corporate assets to the board credibly restrains shareholders from opportunistically liquidating the firm. Thereby, capital is "locked-in" into the corporation, and firm-specific investments by all related parties are facilitated. Extended constitutional rights for shareholders may undermine this function, and as a result, firm value could be reduced.

While the role of credible commitments in corporate governance has received some attention in the theoretical literature, there seems to be no systematic evidence that extended constitutional rights for shareholders seriously impair the growth and longevity of corporations. The case of Swiss corporate law may again serve as an illustration. Firms incorporated in Switzerland grant shareholders very extensive constitutional rights in corporate matters. Nevertheless, this has not adversely affected their ability to attract investors, creditors, employees and customers. The stock market capitalization of Swiss firms relative to GDP, which can serve as a proxy measure for the size of the corporate sector in an economy, is among the highest in the world $(2.17$ in the year 2004, compared to e.g. 1.32 in the United States; Beck, Demirgüç-Kunt and Levine, 2000). Firms also seem to cope well with extended shareholder rights if they are subject to fierce global competition, such as in the banking, insurance, pharmaceutical and food sectors, where Swiss firms are among the largest global corporations. Lastly, extended constitutional rights for shareholders have not damaged relationships between corporations and employees. Although there are usually no formal voting rights for employees in Swiss firms, there are strong "implicit contracts" that corporations will take the interests of employees into account in important corporate matters, which has resulted e.g. in a very low incidence of working days lost due to labor disputes (Monger 2004). Thus, credible commitments that "tie the owner's hands" seem not to offer a major argument for denying shareholders extensive constitutional rights, at least in the case of Switzerland. 


\subsection{Passive shareholders}

A final and maybe the most important counterargument against the constitutional perspective on corporate governance concerns the problem of shareholder passivity (e.g. Black 1990). Extended constitutional rights for shareholders might not serve them well if they are not adequately informed about corporate matters and if they mostly abstain from voting in corporate decisions. Indeed, shareholders face only weak incentives to engage themselves in these respects. Both being informed and participating in corporate decisions are public goods among dispersed shareholder constituencies. If decision-making costs seem too high for shareholders, they may even agree behind the veil of ignorance to delegate most decision-making powers to the corporate board (cf. section 3). Is shareholder passivity thus a main impediment for extended shareholder rights?

There are three arguments why this is unlikely to be the case. First, the main function of extended constitutional rights for shareholders is not that investors actually vote on all major corporate decisions, but that they have the possibility to request a vote if they see a matter as particularly important. This credible threat disciplines corporate boards even if shareholders never decide themselves over a corporate issue. For example, if a corporate board considers whether to pay out a dividend and of what amount, it will take shareholders' views into account ex ante if shareholders can easily overturn the board's proposal. Extended constitutional rights therefore deploy their effects to a large extent in an indirect way, without shareholders having to vote on a large number of corporate decisions.

Second, it can be argued that shareholder passivity is not given, but that it crucially depends on the extent of constitutional rights granted to shareholders. In a system where all major corporate 
decisions are in fact taken by the board, the incentives for shareholders to be informed are indeed quite low. In contrast, a system that grants shareholders extensive constitutional rights is likely to lead to better informed shareholders, because corporate boards have an incentive to become more active in supplying information to investors. In the political sphere, it has been shown that extended constitutional rights for citizens lead to higher levels of voter information in political matters (Benz and Stutzer 2004).

Third, the problems of low information and low turnout levels in corporate decisions are likely to become less important to the extent that institutional investors' influence in corporate governance increases. Institutional investors have much larger incentives to be informed about corporate issues and to use their voting rights, because the size of their equity holdings gives them a real chance to influence corporate decisions. However, the importance of institutional investors is not unproblematic. As has been argued in section 3, institutional investors ought to act in the interests of their ultimate beneficiaries, and those may in turn have low incentives to adequately control their delegates' actions.

In sum, while several counterarguments against a constitutional approach to corporate governance can be brought forward, they do not seem valid enough to suggest that the theoretical perspective proposed is inadequate or that extended constitutional rights for shareholders are impracticable.

\section{Conclusions}

This paper has advanced an alternative approach to the governance of business firms, which we have termed a constitutional theory of corporate governance. The perspective departs from the 
currently prominent notion that there is a uniformly "optimal" governance structure for corporations. Rather, it proposes a different, rules-based view. A corporate governance arrangement should be considered as adequate if shareholders have extended constitutional rights to (at least potentially) freely adopt and change it, and it should be considered as inadequate if shareholders are denied these rights. The focus on the constitutional rights of shareholders is relevant from a theoretical point of view as well as in corporate governance practice. For example, the corporate laws of the United States and Switzerland grant shareholders very different constitutional rights to change the firm's constitution or to initiate specific business decisions, which largely determines their respective possibilities to install corporate governance structures according to their preferences.

The constitutional approach to corporate governance can not only be applied to existing governance arrangements, it can also provide a novel perspective on the superordinate question what corporate law individuals would adopt at a constitutional stage, behind a veil of ignorance. It has been shown that in some areas, the constitutional perspective leads to conclusions that are very similar to what is actually practiced in corporate governance in many countries nowadays. Overall, there seem to be no convincing arguments that individuals would strongly restrict the constitutional rights of shareholders at a constitutional stage. Rather, behind the veil of ignorance, individuals would probably opt for a shareholder right to "choose whether to have a choice", i.e. to decide whether a corporate issue is delegated to the board or whether it is dealt with by shareholders themselves. Moreover, they would likely subject proposed changes in the governance structure of a firm to a supermajority requirement in order to protect minority shareholders. 
The constitutional view of corporate governance can be opposed on several grounds, and we have discussed counterarguments related to potential conflicts between shareholders and stakeholders, the necessity to credibly "lock-in" capital to the firm in order to facilitate firm-specific investments, and the problem of shareholder passivity. None of these counterarguments seems to provide a strong case against granting shareholders extended constitutional rights in matters of corporate governance. If the constitutional theory of corporate governance is correct, these extended constitutional rights for shareholders ought to make a large difference for the actual practice of corporate governance. This implication, however, stands to be more fully investigated in future work. 


\section{References}

Bar-Gill, Oren, Michal Barzuza and Lucian A. Bebchuk (2006). The Market for Corporate Law. Journal of Institutional and Theoretical Economics 162(1): 134-171.

Bebchuk, Lucian A. (2005). The Case for Increasing Shareholder Power. Harvard Law Review 118(3): 833-914.

Bebchuk, Lucian A. (2006). Letting Shareholders Set the Rules. Working Paper, Harvard Law School.

Bebchuk, Lucian A., Alma Cohen and Allen Ferrell (2004). What Matters in Corporate Governance? Working Paper, Harvard Law School.

Becchio, Bruno, Urs Wehinger, Alfred S. Farha and Stanley Siegel (1996). Swiss Company Law. Bern: Stämpfli.

Beck, Thorsten, Asli Demirgüç-Kunt and Ross Levine, (2000). A New Database on Financial Development and Structure. World Bank Economic Review 14(3): 597-605.

Benz. Matthias and Alois Stutzer (2004). Are Voters Better Informed When They Have a Larger Say in Politics? Evidence for the European Union and Switzerland. Public Choice 119(1-2): 31-59.

Benz, Matthias and Bruno S. Frey (2006). Corporate Governance: What Can We Learn from Public Governance? Academy of Management Review, forthcoming.

Black, Bernard S. (1990). Shareholder Passivity Reexamined. Michigan Law Review 89: 520608.

Blair, Margaret M. (2005). The Neglected Benefits of the Corporate Form: Entity Status and the Separation of Asset Ownership from Control. In: Grandori, Anna (ed.). Corporate Governance and Firm Organization. Microfoundations and Structural Forms. Oxford: Oxford University Press, 45-66.

Blair, Margaret M. and Lynn A. Stout (1999). A Team Production Theory of Corporate Law. Virginia Law Review 85: 247-328.

Blair, Margaret M. and Lynn A. Stout (2001). Director Accountability and the Mediating Role of the Corporate Board. Washington University Law Quarterly 79: 403-447.

Brown, Lawrence D. and Marcus L. Caylor (2004). Corporate Governance and Firm Performance. Working Paper, Georgia State University.

Buchanan, James and Gordon Tullock (1962). The Calculus of Consent. Logical Foundations of Constitutional Democracy. Ann Arbor: University of Michigan Press.

Christoffersen, Susan E. K., Christopher C. Geczy, David K. Musto and Adam V. Reed (2005). Vote Trading and Information Aggregation. Working Paper, McGill University.

Cooter, Robert D. (2000). The Strategic Constitution. Princeton: Princeton University Press.

Daily, Catherine M., Dan R. Dalton and Albert A. Cannella (2003). Corporate Governance: Decades of Dialogue and Data. Academy of Management Review 28(3): 371-382. 
Dalton, Dan R., Catherine M. Daily, Alan E. Ellstrand and Johnathan L. Johnson (1998). MetaAnalytic Reviews of Board Composition, Leadership Structure, and Financial Performance. Strategic Management Journal 19: 269-290.

Dalton, Dan R., Catherine M. Daily, S. Trevis Certo and Rungpen Roengpitya (2003). MetaAnalyses of Financial Performance and Equity: Fusion or Confusion? Academy of Management Journal 46(1): 13-26.

Djankov, Simeon, Rafael La Porta, Florencio Lopez-de-Silanes and Andrei Shleifer (2005). The Law and Economics of Self-Dealing. NBER Working Paper No. 11883.

Dostie, Benoit (2005). Job Turnover and Returns to Seniority. Journal of Business and Economic Statistics 23(2): 192-99.

Easterbrook, Frank H. and Daniel R. Fischel (1991). The Economic Structure of Corporate Law. Cambridge: Harvard University Press.

Flabbi, Luca and Andrea Ichino (2001). Productivity, Seniority and Wages: New Evidence from Personnel Data. Labour Economics 8(3): 359-87.

Forstmoser, Peter, Arthur Meier-Hayoz and Peter Nobel (1996). Schweizerisches Aktienrecht. Bern: Stämpfli.

Frey, Bruno S. (1978). Modern Political Economy. Oxford: Blackwell.

Frey, Bruno S. (1983). Democratic Economic Policy. Oxford: Blackwell.

Frey, Bruno S. and Matthias Benz (2005). Can Private Learn from Public Governance? Economic Journal 115(507): F377-396.

Frey, Bruno S. and Margit Osterloh (2005). Yes, Managers Should Be Paid Like Bureaucrats. Journal of Management Inquiry 14(1): 96-112.

Frey, Bruno S. and Alois Stutzer (2006). Direct Democracy: Designing a Living Constitution. In: Congleton, Roger and Birgitta Swedenborg (eds). Democratic Constitutional Design and Public Policy, Analysis and Evidence. Cambridge: MIT Press, forthcoming.

Furubotn, Erik G. (1988). Co-determination and the Modern Theory of the Firm: A PropertyRights Analysis. Journal of Business 61(2): 165-181.

Gifford, Adam (1991). A Constitutional Interpretation of the Firm. Public Choice 68(1-3): 91106.

Gillan, Stuart L. and Laura T. Starks (2003). Corporate Governance, Corporate Ownership, and the Role of Institutional Investors. Journal of Applied Finance 13(2): 4-22.

Gompers, Paul A., Joy L. Ishii and Andrew Metrick (2003). Corporate Governance and Equity Prices. Quarterly Journal of Economics 118(1): 107-155.

Hansmann, Henry and Reinier R. Kraakman (2004a). The Basic Governance Structure. In: Kraakman, Reinier R. et al. The Anatomy of Corporate Law. Oxford: Oxford University Press, 33-70.

Hansmann, Henry and Reinier R. Kraakman (2004b). What Is Corporate Law? In: Kraakman, Reinier R. et al. The Anatomy of Corporate Law. Oxford: Oxford University Press, 1-19. 
Hermalin, Benjamin E. and Michael S. Weisbach (2006). A Framework for Assessing Corporate Governance Reform. NBER Working Paper No. 12050.

Hertig, Gerard (2005). On-Going Board Reforms: One-Size-Fits-All and Regulatory Capture. ECGI Law Working Paper No. 25/2005.

Hertig, Gerard and Hideki Kanda (2004). Creditor Protection. In: Kraakman, Reinier R. et al. The Anatomy of Corporate Law. Oxford: Oxford University Press, 71-99.

Institutional Shareholder Service (2006). Corporate Governance Quotient (CGQ ${ }^{\circledR}$. http://www.issproxy.com/institutional/analytics/uscgqcriteria.jsp (as of June 2006).

Jensen, Michael C. and Kevin J. Murphy (1990). Performance Pay and Top Management Incentives. Journal of Political Economy 98(2): 225-264.

Jensen, Michael C. and William H. Meckling (1976). Theory of the Firm: Managerial Behavior, Agency Costs and Ownership Structure. Journal of Financial Economics 3: 305-60.

Kaisla, Jukka (2001). Extending the Constitutional Theory of the Firm by Introducing Conventions. Working Paper, Copenhagen Business School.

Koehn, Daryl and Joe Ueng (2005). Evaluating the Evaluators: Should Investors Trust Corporate Governance Metrics Ratings? Journal of Management and Governance 9(2): 111-128.

Kraakman, Reinier R., Paul Davies, Henry Hansmann, Gerard Hertig, Klaus J. Hopt, Hideki Kanda and Edward B. Rock (2004). The Anatomy of Corporate Law. A Comparative and Functional Approach. Oxford: Oxford University Press.

Lazear, Edward P. (2003). Firm-Specific Human Capital: A Skill-Weights Approach. NBER Working Paper No. 9679.

Marino, Anthony M. and John G. Matsusaka (2005). Decision Processes, Agency Problems, and Information: An Economic Analysis of Capital Budgeting Procedures. Review of Financial Studies 18(1): 301-325.

Martin, Shaun and Frank Partnoy (2005). Encumbered Shares. University of Illinois Law Review 3: $775-813$.

Matsusaka, John G. (2005). Direct Democracy Works. Journal of Economic Perspectives 19(2): 185-206.

Miller, Gary J. and Dino Falaschetti (1999). Tying the Owner's Hands: The Moral Hazard of Profit-Maximization. Working Paper, Washington University.

Monger, Joanne (2004). International Comparisons of Labour Disputes in 2002. Labour Market Trends, April: 145-152.

Moskovitz, Tobias J. and Annette Vissing-Jorgensen (2002). The Returns to Entrepreneurial Investment: A Private Equity Premium Puzzle? American Economic Review 92(4): 745-778.

Mueller, Dennis C. (1996). Constitutional Democracy. Oxford: Oxford University Press.

Mueller, Dennis C. (2003). Public Choice III. Cambridge: Cambridge University Press.

Osterloh, Margit and Bruno S. Frey (2005). Shareholders Should Welcome Knowledge Workers as Directors. Institute for Empirical Research in Economics Working Paper No. 283, University of Zurich. 
Rawls, John (1971). A Theory of Justice. Cambridge: Harvard University Press.

Roberts, John and Eric Van den Steen (2000). Shareholder Interests, Human Capital Investments and Corporate Governance. Stanford University, Graduate School of Business Working Paper No. 1631.

Romme, A. Georges L. (2004). Unanimity Rule and Organizational Decision Making: A Simulation Model. Organization Science 15(6): 704-718.

Shleifer, Andrei and Robert W. Vishny (1997). A Survey of Corporate Governance. Journal of Finance 52(2): 737-778.

Topel, Robert (1991). Specific Capital, Mobility, and Wages: Wages Rise with Job Seniority. Journal of Political Economy 99(1): 145-176.

Vanberg, Viktor (1992). Organizations as Constitutional Systems. Constitutional Political Economy 3(2): 223-253.

Woidtke, Tracie (2002). Agents Watching Agents?: Evidence From Pension Fund Ownership and Firm Value. Journal of Financial Economics 63(1): 99-131.

Wolff, Brigitta (1997). Constitutional Contracting and Corporate Constitution. In: Picot, Arnold and Ekkehart Schlicht (eds.). Firms, Markets, and Contracts. Contributions to Neoinstitutional Economics. Heidelberg: Physica-Verlag, 95-108. 